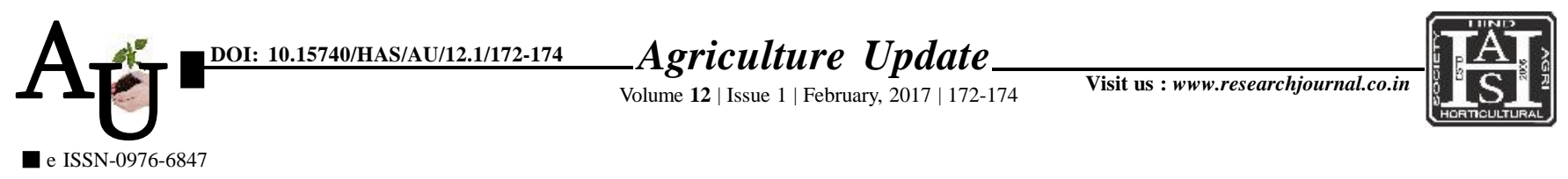

\title{
Research Note: Production constraints of maize cultivation under Mokokchung district of Nagaland
}

PIJUSH KANTI BISWAS, RAJIB DAS AND SAMUEL SANGTAM

Article Chronicle:

Received :

23.11.2016;

Accepted :

27.01.2017

KEY WoRdS :

Constraints, High

quality maize,

Villages, Production
SUMMARY : The present study was conducted in Mokokchung district of Nagaland. Purposively eight villages were selected from four selected rural development (RD) blocks. From those eight villages 200 respondents were selected randomly. The study reveals that the major constrains of high quality protein maize production was noted in non-availability of quality seed by 89.50 per cent of the respondents which comes under infrastructural constraint.

How to cite this article : Biswas, Pijush Kanti, Das, Rajib and Sangtam, Samuel (2017). Production constraints of maize cultivation under Mokokchung district of Nagaland. Agric. Update, 12(1): 172-174; DOI : 10.15740/ HAS/AU/12.1/172-174. 